\title{
The familiar and the foreign: Finnish landscapes in contemporary Irish poetry
}

\section{Anne Karhio}

\section{Q OpenEdition \\ 1 Journals}

\section{Electronic version}

URL: http://journals.openedition.org/etudesirlandaises/3825

DOI: 10.4000/etudesirlandaises.3825

ISSN: 2259-8863

\section{Publisher}

Presses universitaires de Rennes

\section{Printed version}

Date of publication: 30 June 2014

Number of pages: 183-204

ISBN: 978-2-7535-3449-0

ISSN: 0183-973X

\section{Electronic reference}

Anne Karhio, "The familiar and the foreign: Finnish landscapes in contemporary Irish poetry », Études irlandaises [Online], 39-1 | 2014, Online since 30 June 2016, connection on 22 April 2019. URL : http:// journals.openedition.org/etudesirlandaises/3825 ; DOI : 10.4000/etudesirlandaises.3825 


\title{
The Familiar and the Foreign: Finnish Landscapes in Contemporary Irish Poetry
}

\author{
Anne Karhio \\ The University of Stavanger
}

Abstract

This essay focuses on contemporary Irish poets' engagement with Finnish landscapes, more specifically on poems drawing on Finnish art, culture and history. It examines how Irish poets negotiate between the "familiar and the foreign", as Edna Longley has phrased it, in adapting Finnish material to address cultural and personal crises in new contexts. Three poems by Michael Hartnett, Seamus Heaney and Tom Paulin are discussed as instances of de- and re-contextualising recognisably Finnish motifs and art works, often in order to rise above the social and political pressures of specific cultural frameworks.

Keywords: Poetry; Seamus Heaney; Michael Hartnett; Tom Paulin; landscape; Ireland/ Finland

\section{Résumé}

Cet essai examine l'engagement des poètes irlandais contemporains avec le paysage finlandais, et plus particulièrement les poèmes inspirés des paysages, de l'art, de la culture et de l'histoire finlandais. Il analyse comment les poètes irlandais négocient entre "le familier et l'étranger ", pour reprendre la formulation d'Edna Longley, en adaptant des textes finlandais afin de replacer les crises culturelles et personnelles dans de nouveaux contextes. Les poèmes de Michael Hartnett, Seamus Heaney et Tom Paulin sont considérés comme des exemples de décontextualisation et recontextualisation d'ceuvres et motifs typiquement finlandais, souvent dans le but de sélever au-dessus des pressions sociales et culturelles des cadres culturels spécifiques.

Mots clés : Poésie; Seamus Heaney; Michael Hartnett; Tom Paulin; paysage; Irlande/Finlande

In her essay "Irish Poetry and 'Internationalism", Edna Longley interrogates the perceptions of increasing openness to the outside world apparent in recent Irish poetry. Not only does she remind us that various transnational crosscurrents were already constitutive of much of the writings of Yeats's and Beckett's poetry. She also highlights how the "question of Abroad in Irish literature has been only patchily explored" due to the routes determined by the popularity of concepts and paradigms of "exile", "emigration" and "colonialism"1. This essay adds to the patchwork

1. Edna Longley, "Irish Poetry and 'Internationalism': Variations on a Critical Theme”, The Irish Review, $\mathrm{n}^{\circ} 30$ 
of "international" perspectives on Irish poetry in its discussion of Irish poets' engagement with Finland and representations of its landscape in visual arts, music and autobiographical writing. What it seeks to do is to approach one particular aspect of "abroad" as a series of not quite isolated but more subtly interrelated occurrences of Finland in three poems: Michael Hartnett's "Sibelius in Silence", Seamus Heaney's "Known World" (Electric Light, 2001) and Tom Paulin's "Trotsky in Finland" (The Strange Museum, 1980). In other words, the focus will be on cross-cultural exchanges or displacements which allow poets to de- and re-contextualise their themes and subject matter and thus question the premises underlying their familiar personal and cultural contexts. Longley quotes Pierre Bourdieu, for whom, in the process of certain type of "internationalization", "texts circulate without context... they don't bring with them the field of production of which they are a product, and the fact that the recipients, who are themselves in a different field of production, re-interpret the texts in accordance with the structure of the field of reception... generates some formidable misunderstandings" ${ }^{20}$. Such misunderstandings can be liberating in a literary culture where any reference to the domestic landscape is immediately conditioned by the densely layered narratives of the native terrain, and where, as Seamus Heaney puts it in "Bogland", "Every layer... seems camped on before". At the same time, as Longley notes, "any poet seizes on the familiar in the foreign $[\ldots]$ to elaborate a pre-existing myth or trope ${ }^{4}$ ". The importance of understanding exchanges across national borders less in terms of internationalism or the "coercive categories like 'exile', 'emigration' and 'colonialism's" (though these categories need not necessarily be "coercive") and more through the aleatory ways in which "poetry...smuggles strangeness across frontiers" directs the following discussion on the appropriation of Finnish landscape and its aesthetic representation by contemporary Irish poets. The interplay between the familiar and the strange or foreign can thus be seen as a variable of the processes of estrangement, Skhlovsky's ostranenie, whereby poetry as a verbal art acts to "make objects 'unfamiliar"'?". The habitual links between narrative and landscape in one personal or cultural context are severed and questioned through the introduction of a new topography.

The three poems discussed below are by no means the only instances where Finland has left a mark on Ireland's literary terrain. Heaney's "Known World" is preceded by "Audenesque", in which the recollections of icy north are counter-

(Spring-Summer, 2003), p. 48-49.

2. Bourdieu in Longley, "Internationalism", p. 53-54.

3. Seamus Heaney, Door Into the Dark, London, Faber and Faber, 1969, p. 56.

4. Longley, "Internationalism", p. 53.

5. Ibid., 49.

6. Ibid., 53.

7. Viktor Skhlovsky, "Art as Technique", in Lee T. Lemon and Marion J. Reis (eds.), Russian Formalist Criticism: Four Essays, Lincoln (NE), University of Nebraska Press, 1965, p. 12. 
balanced against a memory of a summer train trip with the fellow poet Joseph Brodsky in Finland; like Heaney, Paul Durcan draws on Simberg's "Wounded Angel" to frame a personal narrative in "The Children of Lir - After Hugo Simberg"; Dorothy Molloy's "Ice Maiden" opens with the speaker imagining herself "walk[ing] in [her] night-dress and slippers/along winter beaches in Finland". And, in a characteristically oblique manner, Finnish topography smuggles its way into Medbh McGuckian's "The Man with Two Women”, which quotes, almost word for word, Ann and Samuel Charters' biography of Vladimir Mayakovsky, and an account of the Russian poet's stay in Finland, but leaves out the specific markers of geographical location; the original "Kuokkala was a country resort in the sparse pine woods on the shores of Finland, with a gritty beach that had huge stones protruding irregularly from the water" is condensed to an image of "a gritty beach/With huge stones,/where I could sit". Perhaps the most notable single instance of a Finnish-Irish exchange not discussed here, one which negotiates the permeable borders of the personal and the cultural, the familiar and the foreign or strange, is Peter Sirr's long poem "A Journal", an account of the end of an affair with a Finnish lover. The context of Sirr's poem is highly personal, and a perfect example of how individual circumstances may circumvent any wider cultural frameworks. The poet goes as far as to never name the cities, one in Finland, one in Ireland, which provide the two geographical poles for the two individuals' experiences. Rather than any specific place, the poem attempts to orientate itself in a "huge space, unmappable", and focuses on spatial imagery (rooms and streets, inside and outside) constantly resisting contextualization, and the slipperiness of memory is further illustrated through the imagery of water. Sirr's lines consist of "words without landscape", a topography too private to comfortably settle in any specific places and experiences ${ }^{8}$.

All of the poems listed above have their spatial contexts, of course, and also, no matter how fleetingly, form brief attachments with Finnish landscapes. The present essay will, however, focus on the three poems by Hartnett, Heaney and Paulin as examples that perhaps best illustrate the tensions between the familiar and foreign in the Finnish-Irish encounters in contemporary Irish poetry in their respective representations of landscape. Their connections with Finnish culture, arts and aesthetics also share a certain historical framework. Finnish symbolist painter Hugo Simberg's "The Wounded Angel" that inspired Heaney's

8. Seamus Heaney, Electric Light, London, Faber and Faber, 2001, p. 77; Paul Durcan, Daddy, Daddy, Belfast: Blackstaff Press, 1990, p. 171-172; Dorothy Molloy, Hare Soup, London, Faber and Faber, 2004, p. 10; Medbh McGuckian, Marconi's Cottage, Oldcastle, County Meath, Gallery Press, 1991, p. 14 (Charters' monograph quoted in Shane Alcobia-Murphy, Sympathetic Ink: Intertextual Relations in Northern Irish Poetry, Liverpool, Liverpool University Press, 2006, 64) ; Peter Sirr, The Ledger of Fruitful Exchange, Oldcastle, Country Meath, Gallery Press, 1995, p. 57-90. 
poem "Known World" was finished in 1903, and Paulin's lyric narration of Leon Trotsky's stay in Finland, titled simply "Trotsky in Finland" draws on events in the winter of 1905. While Hartnett's long poem "Sibelius in Silence" is set in a later period, one of the composer's creative silence from 1926 onwards, the poem repeatedly returns to issues topical in the first years of the $20^{\text {th }}$ century in Finland, including the struggle under the Russian rule and the cultural construction of the nation. The period was one of intense artistic production in the country, during which the forging of national art and literature was counterbalanced by cosmopolitanism and nascent modernism. At the same time, the rising class-consciousness among the Finnish rural labourers and industrial working class would draw on the more international cross-currents of the rise of socialism, eventually leading to the Finnish civil war in 1918, in the aftermath of the Russian revolution and Finnish independence in 1917.

However, national and cultural identity is in no way an overarching theme in the three poems discussed here; only in "Sibelius in Silence" is cultural nationalism interrogated in any more extensive manner, and even that poem balances its considerations of a national-cultural community against individual predicaments not easily summarized under any single critical paradigm. What all three poems, and all three works they engage with share, however, is an engagement with and representation of a landscape which may be recognizable as "Finnish" but which, more importantly, provides a setting for concerns of less easily definable geographical origins. The change of context outlined by Bourdieu in the quotation above, in other words the circulation of motifs or texts from one context to another, here leads to the emergence of literary topographies which draw on landscapes on the opposite side of Europe to rewrite those closer to home.

Oona Frawley has suggested that representations of landscape in $19^{\text {th }}$ and $20^{\text {th }}$ century Irish literature are frequently characterized by nostalgia, and are thus marked by both continuity and loss. She notes that "nostalgia serves [...] as a safety mechanism designed to bridge past and present for cultures as they experience change"”. Frawley is here commenting on Irish culture and literature, but similarly in Finland, especially in the early $20^{\text {th }}$ century, landscape in the arts was used to forge legitimacy for the emerging national consciousness; the often romanticized ideal of the national landscape, tinged with nostalgia, persists until today, as it does in Ireland ${ }^{10}$. But the poems examined here do not neatly fall under such a paradigm. Rather, I argue that the constructions of landscape

9. Oona Frawley, Irish Pastoral: Nostalgia and Twentieth-Century Irish Literature, Dublin, Irish Academic Press, 2005 , p. 3.

10. See for example Pekka Vähäkangas, "Paikallisuus ja kansallisuus suomalaisessa kuvataiteessa" ("Locality and nationality in Finnish arts"), lecture at the University of Jyväskylä, 1 January 1999. [http://www.finnica.fl luennot/99syys/vahakangas.htm, date accessed 28 January 2012]. 
in these poems provide their respective authors with spatial allegories that allow them to investigate preoccupations specific to their respective poetic endeavours. The poets engage with depictions of landscape as encountered in visual arts, music or autobiographical writing, and in their reading of these landscapes they also rewrite them from more familiar personal and cultural coordinates. Or, as J. Hillis Miller formulates it, the emergence of their respective textual topographies are simultaneous acts of "creating" and "revealing"11.

For Michael Hartnett, the arduous relationship between life and art, and the struggle of the artist with a divided heritage and his decline into alcoholism made him turn to Sibelius, the Finnish symphonist for whom the creative process was similarly marked by darker impulses. Seamus Heaney, whose poetry has repeatedly returned to the author's domestic landscape in county Derry, explores an encounter with atrocities evoking familiarity and strangeness in the Balkans through a painting from a different extreme of Europe, as he contemplates the relationship between art, violence and suffering through the work of Hugo Simberg. Finally, I will look at a poem by Tom Paulin, the controversially political Ulster Protestant whose polemic insistence on the interrelationship between poetry and politics turns to one of the most famous revolutionary figures of the $20^{\text {th }}$ century, namely Leon Trotsky, and his journey through the Finnish countryside as depicted in his memoir; in Paulin's poem, Finland emerges as a liminal zone between the West and the East.

The musical theme of Hartnett's "Sibelius in Silence" binds Sibelius's ailing creative powers to Hartnett's similar struggle: Hartnett also spent the final years of his life in relative artistic silence ${ }^{12}$. It also links with Hartnett's relationship to the Irish musical tradition: as Seamus Deane has noted, the emerging Irish poetry in English in the 19th century, from Thomas Moore to James Clarence Mangan, would find an audience through allying itself with Irish music, an "indigenous" cultural practice, to legitimize a literature produced in the language of the colonizer $^{13}$. As a result, concludes Dillon Johnston, for contemporary Irish poets an

11. J. Hillis Miller, Topographies, Stanford, California, Stanford University Press, 1995, p. 6.

12. Hartnett, as Durcan notes, "after the publication of Sibelius in silence was to write no more serious original poetry until his death in 1999". See Paul Durcan, "Hartnett's Farewell", The Poet's Chair: The First Nine Years of the Ireland Chair of Poetry, John Montague, Nuala Ní Dhomhnaill and Paul Durcan (eds.), Dublin, The Lilliput Press, 2008, p. 200.

13. Deane quoted in Seán Crosson, The Given Note: Traditional Music and Modern Irish Poetry, Cambridge Scholars Publishing, Newcastle-upon-Tyne, Newcastle, Cambridge Scholar's Publishing, 2008, p. 76. While Mangan's engagement with the Irish musical tradition may not have been as extensive or explicit as Moore's, the role of the song tradition fulfilled an important function in his work, as is did in the work of the other poets associated with the nationalist newspaper The Nation. As Crosson outlines, Mangan's translations from Gaelic, Poets and Poetry of Munster, was accompanied by music to which they were to be sung while his first contribution to The Nation was meant to be sung to the music of “Rory O'More”. In addition, Mangan's free translation of 
"enthusiasm for traditional Irish music seems as pervasive [...] as their interest in Gaelic $^{14 ”}$. A parallel can be drawn between the importance of music to the Irish poetic tradition and the significance of Sibelius's music to the rising Finnish national consciousness, as well as his use of the folk motifs from Finnish mythology in his work. Eoin Flannery has noted how

Hartnett's poetry is not only sustained by a conscious genealogical and formal attachment to the eighteenth-century Munster bardic poets ${ }^{15}$, his work is also close to the cultural and physical landscape out of which it emanates. In a poem such as "Sibelius in Silence", in which Hartnett the poet is brought to a form of creative, linguistic crisis, we can locate a joining of these twin artistic and historical concerns ${ }^{16}$.

The motif of landscape is particularly prominent in Hartnett's troubled hommage to the Finnish composer, and the simultaneous attachment to and alienation from the landscape sustaining the poet and the composer is a crucial preoccupation in the poem: the complexities of belonging and estrangement are in both cases linked to the historical rifts between people, land and language in the homelands of the two artists. Hartnett's concerns and anxieties over the fate of the language and tradition of Irish poetry eventually led the poet to abandon the idiom of the colonizers, "the perfect language to sell pigs in ${ }^{17 "}$. For his Sibelius, the struggle with language and identity is of a more complex kind, as the composer came from a Swedish-speaking family and only learned the Finnish language at the age of eight ${ }^{18}$. The composer sought to affirm his allegiances to the nation,

the Gaelic song "Róisín Dubh" [as "Dark Rosaleen”] has been described as the "most widely known nationalist poem" of the nineteenth century (p. 76).

14. Dillon Johnston, Irish Poetry After Joyce, Syracuse, Syracuse University Press, 1997, p. 47. Of the poets discussed in this essay, the views of Tom Paulin on the purported union of music, language and cultural identity draw from a very different kind of narrative of Irish culture and history; while Paulin has envisioned an Ireland where Irish, Ulster Scots and Hiberno - English would contribute to the cultural and linguistic tapestry of the nation, his enthusiasm for bringing together music and poetry in cultural politics would be somewhat more reserved; he has, for example, accused Thomas Moore for reducing the political aspirations of Irish poetry "into lilting anapests" (see Paulin, Field Day Theatre Company, Ireland's Field Day, The University of Notre Dame Press, 1986, p. 15 and Paulin quoted in Harry White, Music and the Irish Literary Imagination, Oxford, Oxford University Press, 2008, p. 41).

15. In "A Farewell to English", for example, Hartnett speaks of Croom, County Limerick, which, he writes in a footnote, was his birthplace as well as the "seat of the last 'courts' of Gaelic poetry", and lists it alongside place names associated with the great bardic poets Aodhagán Ó Rathaille and Dáithí Ó Bruadair (Michael Hartnett, A Farewell to English, Peter Fallon [ed.], Dublin, Gallery Press, 1978, p. 63).

16. Eoin Flannery, "Landscape, language and cultural memory in the poetry of Michael Hartnett", Remembering Michael Hartnett, Stephen Newman and John McDonagh (eds.), Dublin, Four Courts Press, 2006, p. 163.

17. A Farewell to English, p. 67.

18. While there are parallels between Finnish and Irish history and ideas of language as a marker of national identity, it is also important to keep in mind that in Finland the language question was markedly different in the sense that Finnish never suffered of a similar near-eradication as Irish did; furthermore, the Swedish-speaking intelligentsia (including figures like Elias Lönnrot, J. V. Snellman and Sakari Topelius) of Finland were, ironi- 
perhaps most famously through the composition of Finlandia in the final years of the $19^{\text {th }}$ century. However, a comfortable sense of belonging is, in Hartnett's poem, seen to be denied to Sibelius who stood up against the oppressive measures of Nikolai II's Czarist Russia, though himself speaking the language of previous colonizers ${ }^{19}$.

Hartnett opens his poem with an evocation of the arrival of Finns to the land released from under the burden of the ice age:

To have intricacies of lakes and forests, harbours, hills and inlets given and none of these with a name; then to have posited nomads straggling from the barricading Urals, bearing on their backs and horses children, language and utensils, gods and legends; then to have brought all these together, yeast to the thawing mud this was to make in the Green Gold of the North an ethnic and enduring bread ${ }^{20}$.

The land is imagined almost virginal, as void of human presence, while at the same time a ground for growing roots. Or rather, the imagined fertility of the landscape is described as a fermenting process, where the coming together of "yeast" and "mud" will create "enduring bread": the forging of a nation is a result not of spontaneous birth but of arduous labour (one also illustrated by the sound patterns of the lines), and the claim to land by its people based on toil and

cally, the main supporters of Finnish language education and cultural production in the country (on Sibelius, Finnish language and nationalism see for example Glenda Dawn Goss, Sibelius: A Composer's Life and the Awakening of Finland, Chicago, The University of Chicago Press, 2009). Consequently, Hartnett may be projecting on Sibelius a sense of cultural guilt and self-consciousness over the language question which more accurately reflects his own attitudes towards the language of the "colonizer".

19. In the still-autonomous Grand Duchy of Finland, struggling under the oppressive measures of Nikolai II and his governor Bobrikov, it was, however, Russian which was considered the language of the foreign rule, threatening the role of "national languages", in the plural, as Erik Tawastjerna puts it. See Erik Tawaststjerna, Sibelius. Suuri suomalainen kirjakerho, Helsinki, p. 143. As a poem displacing personal and cultural sense of crisis into a foreign landscape, "Sibelius in Silence" aligns itself with that of another Irish poet with an awareness of the cultural complexities inscribed in material and literal landscapes, namely John Hewitt's "The Colony". Hewitt's poem, the poet himself contends, "allegorize[s] the regional circumstance [of Northern Ireland] as that of a Roman Colony" (John Hewitt, "No Rootless Colonist", Ancestral Voices: The Selected Prose of John Hewitt, Tom Clyde [ed.], Belfast, Blackstaff Press, 1987, p. 146-157). The method or "evasive technique", as Sam Robertson has observed, similarly gives the poet a certain liberty to address conflict and crisis in one specific location and landscape through displacing it into another ("John Hewitt's allegorical imagination", Irish Studies Review, Vol. 17, n 2, May 2009, p. 174-175).

20. Michael Hartnett, "Sibelius in Silence", Poetry Ireland Review, No. 37, Winter, 1992/1993, p. 25. 
struggle after their arrival - not as growing naturally from the soil. But it is specifically this claim that leads to a struggle of another kind by the composer, as he seeks to align himself with the emerging national consciousness.

After the land is first immersed

in language, gods and legends,

sown with blood and bodies,

whatever strangers come and conquer

and stand upon the hills at evening

(for we, the planters, tend to meditation),

they will sense they are not wanted here ${ }^{21}$.

The "planters" are also called "mapping strangers" in the poem, and the vocabulary betrays Hartnett's Irish preoccupations; the processes of "planting" and "mapping" are rarely evoked in the Finnish popular consciousness, when it comes to the occupying of the country by Swedish or Russian rulers. (As Kuortti, Lehtonen and Löytty have observed, the understanding of Finland as a "postcolonial" nation has yet to establish itself as a popular or scholarly paradigm ${ }^{22}$.)

But if security as belonging due to a linguistic background was something unavailable to Sibelius, Hartnett's composer finds a way forward, if not, as the poem puts it, "a way home", in music.

Blacker than the blackest swans are, all my life their mythic figures

clothed in insistent rhythms

have pursued me and made me anxious,

called my name and demanded answers:

and I listened. And I answered.

Music was my language, so I gave them my music;

and the land drank in my music ${ }^{23}$.

Sibelius drew repeatedly on the oral tradition and mythology that inspired Elias Lönnrot's Kalevala, for example in his "Swan of Tuonela", a part of the Lemminkäinen Suite (a project apparently started in the final years of the $19^{\text {th }}$ century but first performed in its entirety in 1935). The association of the swan with "blackness" also comes from Kalevala, where the swan, a sacred bird in eastern Finnish mythology, would swim in the river of death. Here, the use of mytho-

21. Hartnett, "Sibelius in Silence", p. 25-26.

22. Joel Kuortti, Mikko Lehtonen \& Olli Löytty in their recent volume of essays Kolonialismin jäljet, (The Traces of Colonialism) state that their work is one of the relatively few to examine Finnish history as colonial, and modern Finland as a postcolonial society. See Kuortti, Lehtonen and Löytty, Kolonialismin Jäljet, Helsinki, Gaudeamus, 2007.

23. Hartnett, "Sibelius in Silence", p. 27-28. 
logy offers a way to connect, through music, to a tradition the composer feels he cannot quite claim as his own, and consequently becomes an inseparable part of Finnish cultural heritage and identity; as Paul Durcan points out, Sibelius's "Finlandia", for example, "was and [...] remains Finland's unofficial national anthem. [It] is to Finns what Ó Riada's Mise Eire used to be to many Irish people ${ }^{24 "}$. The evocation of mythology through music enables the Irish poet's Sibelius to engage in the same process of "the craft of the bard" which Flannery considers pivotal to Hartnett's own pursuits ${ }^{25}$. Music here signifies a path to a tribal landscape which cannot be accessed through language in a linguistically ruptured or fragmented culture, a means to express the "non-verbal communication between the tribe and

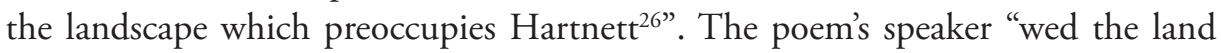
and dreamed her freedom/somehow coalesced and marched maestoso/out through the hatchings of my music-sheets ${ }^{27}$. Hartnett's engagement with language, landscape and music in "Sibelius in Silence" thus seeks to access through poetry a close relationship between person, community and landscape in a cultural moment of historical and linguistic crisis. In other words, the evocation, even in verbal utterance, of the non-verbal registers of music enables the poet to imagine continuities through artistic expression even when such continuities have been fractured by historical processes. For Sibelius, music was a language of its own which did not always yield to verbal constraints. In 1919, he defended in an interview his decision not to give a title to his fifth symphony in saying that the work was "pure music" and "musical thoughts" and could not, therefore, have a name. For the composer there were ideas that could only be expressed through music ${ }^{28}$. For the poet Hartnett, however, the translation of landscape into language, and the transcription of place-names into the idiom of the coloniser has to be addressed verbally:

it watches rivers wash

its labels from their banks

contemptuously to sea,

watches names it put on hills

detach themselves doggedly slide down

a valley of unwanted nouns ${ }^{29}$.

Landscape, in "Sibelius in Silence", does not yield to the kind of power exercised through mapping and naming, as carried out in Ireland by the British ord-

24. Durcan, "Hartnett's Farewell", p. 199, sineadh fada missing in the original.

25. Flannery, p. 161.

26. Ibid., p. 167.

27. Hartnett, "Sibelius", p. 28.

28. Tawaststjerna, p. 319.

29. Hartnett, "Sibelius", p. 26. 
nance survey; For Paul Durcan, the lines evoke Friel's Translations, and he notes how "[f]rom the landscape of Finland Hartnett transports the Sibelian voice to the hinterland of his native town Newcastle West in County Limerick ${ }^{30}$ ”.

It is towards the end of the poem that the description of physical landscape yields to a landscape of the mind as expressed through music, and Hartnett's Sibelius is envisioned as conducting the fourth symphony, which has been said to be stripped of all unnecessary "pretence ${ }^{31}$ ":

They say my music weeps for the days

when my people ate the bark from trees

because all crops had failed.

Music disdains such theories:

I offer you here cold pure water

as against the ten-course tone-poems, the indigestible Mahlerian feasts;

as against the cocktails' many hues,

- all liquors crammed in one glass -

pure cold water is what I offer.

Composed, I am conducting. It is my

fourth symphony, thrid [sic] movement and,

as my baton tries to make the music keep

to the key of $\mathrm{C}$ sharp minor,

vodka ebbs in tremors from my hand ${ }^{32}$

and at the ravaged corner of my eye

a raven flies through the concert hall

and I find a self saying to my self

"it was the deer that stripped the trees

not the people at all."

Two flutes grapple with an ice-cold note

until the 'cello takes command.

As the audience's hiss escapes

splinters of birch-bark stick in my throat ${ }^{33}$.

30. Durcan, "Hartnett's Farewell”, p. 210.

31. For a more detailed description and analysis of the symphony, see for example Sibelius, "Sinfonia IV op. 63 (1911)", [http://www.sibelius.fi/suomi/musiikki/ork_sinf_04.htmhttp://www.sibelius.filsuomi/musiikki/ork_sinf_04. htm], date accessed 14 January, 2014.

32. Though Sibelius himself believed his tremors were caused by the nerves, and alcohol has been seen as one explanation, most recent medical research indicates that the composer's shaking hands were a result of a genetic medical condition. See Vesa Sirén, "Sibeliuksen ja kymmenientuhansien suomalaisten vapinaan löytyi syy", Helsingin Sanomat, 28 January 2012, [http://www.hs.fi/kulttuuri/Sibeliuksen+ja+kymmenientuhansien+suomalai sten+vapinaan+l\%C3\%B6ytyi+syy/a1305554379014], date accessed 28 January 2012.

33. Hartnett, "Sibelius", p. 29. 
Here, Hartnett's Sibelius echoes the historical one, for whom music could not have a similar referential relationship to the world as words; this would make the entire art pointless. "Music, pure music, cannot have a literal content ${ }^{34}$." In the poem, pure fluidity of music takes over from the solidity of bark and "ten course" feasts, even alcohol ${ }^{35}$. From the "enduring bread" which emerges from the landscape, the poem has now moved to the clarity of water, until the verse's final line where "birch-bark stick[s]" in the speaker's throat, signalling the fall into ultimate silence (though not quite biographically, as Sibelius was to compose altogether seven symphonies). Instead of a constructed physical landscape, the "rise" and "ebb" of the music, and the movement of sound now create a topography of their own. According to Durcan, Hartnett in his poem

contrives to convince us that his language is music through the medium of the language of poetry; more subtly, we know that Hartnett's language is poetry and yet by his doubling of Sibelius, he is able to convince us that his language is music ${ }^{36}$.

At the very end of the poem, Sibelius, now surrendering to the quietude of his final years, returns back in time while listening to the radio: "I shuffle to the radio, switch on the set/and pluck, as I did before, Finlandia out of the air ${ }^{37}$." But silence, here, is not merely a failure of creativity, but the aim of music; or as Sibelius wrote in his diaries, expanding on Walter Pater's famous maxim: "What happens when music ceases? Silence. All the other arts aspire to the condition of music. What does music aspire to? Silence." (Durcan, "Hartnett's Farewell", 222.) The landscape forged with such great struggle earlier on in the poem has to disperse into silence, out of which music may grow again; in the end, the poem forms a circle, though with a slight sense of unease - Finlandia, after all, is closely tied to the Finnish national romanticist movement, and its perceived union between art, the people, and their national terrain. Land and air, historical commitment and artistic inspiration, intertwine, but their relationship is never entirely resolved by Hartnett.

34. Tawaststjerna, p. 319, my translation from the original Finnish.

35. Hartnett here, as in numerous other passages of the poem, relies on the composer's diary entries, partially published in his biography. See Tawastjerna and Durcan, "Hartnett's Farewell".

36. Durcan, "Hartnett's Farewell”, p. 213.

37. Hartnett, "Sibelius", p. 30. Sibelius himself contended, when considering the surprising popularity of his tone poem (a piece he considered inferior to his symphonic pieces), that it was the "plein air" quality of the piece which appealed to the audiences, that the piece was "given from above", "pure inspiration" (Tawaststjerna, 140). It is also difficult to read these lines without linking them with an earlier Irish poem on musical inspiration, namely Seamus Heaney's "The Given Note", in which a tune is said to have emerged "out of the night", "[o] ut of wind off mid-Atlantic / Still he maintains, from nowhere./It comes off the bow gravely,/Rephrases itself into the air" (Seamus Heaney, Opened Ground, Poems 1966-1996, London, Faber and Faber, 1998, p. 36). 
The uprooting of Sibelius and his personal and artistic preoccupations from late $19^{\text {th }}$ century and early $20^{\text {th }}$ century Finland, and the working of the poetic landscape of Ireland and Hartnett's Newcastle West exemplify a dynamic of home and away, "the familiar and the foreign ${ }^{38}$ " in Irish poetry in a way which avoids the pitfalls of national versus international categorization concerning Longley. The emerging landscape of the poem cannot in any straightforward terms be reduced to that of either geographical location, and the complex interplay between musical, literary and physical landscapes reflects the equally complex dialogue between artists separated in time and space, but simultaneously sharing predicaments not reducible to national or cultural paradigms - what preoccupies the artist of "Sibelius in Silence" is the anchoring of his work to culture, land and landscape, and his simultaneous commitment to the aesthetic and artistic process itself.

For Seamus Heaney, an evoking of the non-verbal forms of communication to poetically access a moment of violent crisis is enabled by an ekphrastic engagement with the Finnish symbolist painter Hugo Simberg's "The Wounded Angel", completed in 1903. The painting depicts two boys carrying a blindfolded angel on a stretcher through a desolate lake - or seashore landscape. At the time of painting "The Wounded Angel", the artist was recovering from a serious illness, which may have contributed to his depiction of the frail figure of the angel, as well as to the bleak backdrop to the figures in the foreground. The painting has been a repeated source of inspiration for poets and other artists, in Ireland and elsewhere ${ }^{39}$.

According to Edna Longley, "[p]oetry's consciousness of painting inevitably highlights and measures its aesthetic self-consciousness, tilts the see-saw away from history". As Shane Murphy has stressed, however, "[ $[\mathrm{t}] \mathrm{he}$ act of looking in Northern Irish poetry is not always innocent, especially when there are socio-political forces involved ${ }^{40}$ ". While "Known World" is not primarily concerned with Northern Ireland or the Troubles, the function of painting in the poem certainly serves to highlight rather than to sidestep historical circumstances, albeit that the

38. Longley, "Internationalism", p. 53.

39. In Ireland, see, for example Rosalin Blue's, 'Blasphemy' (The Irish Examiner (USA), 19 August 2009, [http:// www.irishexaminerusa.com/mt/2009/08/19/ronnie_meginns_poetry_page_121.html], date accessed 14 February 2011), and cover illustration for John Spillane's The Gaelic Hit Factory (John Spillane with Louis de Paor, The Gaelic Hit Factory, released 13 October 2006, EMI). For other responses, see for example John Burnside, “The Wounded Angel - After Hugo Simberg” (Irish Pages, vol. 1, n 1, Spring, 2002, p. 212-213); Lance Olsen, "The Wounded Angel” (The Iowa Review, vol. 33, n 1, Spring, 2003, pp. 109-121). For references in popular culture, see for example Finnish rock group Nightwish's video "Amaranth" ([http://www.youtube.com/ watch? $v=054 n \times x n t 140$ ], date accessed 28 February 2011).

40. Shane Murphy, "The Eye that Scanned It: The Picture Poems of Heaney, Muldoon, and McGuckian”, The New Hibernia Review / Iris Éireannach Nua, Issue 4, Vol. 4 (Winter 2000), p. 90. 
use of the painting allows for the poet to step back from any particular crisis examined to reveal the human propensity for suffering from a more universal perspective. Rather than tensions between cultural and historical context, and aesthetic expression in Hartnett, Heaney's poem focuses on the possibility of addressing the shared human experiences of pain and loss through art and poetry.

To which degree Simberg's, and subsequently Heaney's, landscape is Finnish, is open to question: while it has been suggested that the painter was inspired by the shores of the bay of Töolönlahti in central Helsinki (it was in this landscape the artist was treated for his illness), Simberg himself insisted on the ambiguity of its precise geographical or historical context. The work completed during what has been called the Golden Age of Finnish Art (1880-1910), a period marked by national romantic emphasis in the arts gradually making way for the more frequent exchanges by Finnish artists with their peers in Europe, and the emerging of symbolist and early modernist undercurrents of their work. As Pekka Vähänkangas has noted, symbolism and early modernism turned many Finnish artists away from the panoramic sceneries of lakes and forests, and to more symbolic and ambiguous, subjective landscapes of the mind ${ }^{41}$. Simberg's work, for example, was heavily influenced by European symbolism and later impressionism, though the painter was also highly original in his combination of naivistic dream imagery and rural Finnish landscapes, and studied under the tutelage of Akseli Gallen-Kallela.

Heaney's poem refers to the later of the two versions of the painting produced by Simberg: the original oil on canvas was completed in 1903, but in 19051906, the artist painted a second version as a fresco on the walls of the Tampere Cathedral. While the two images are nearly identical, the latter includes the two "factory chimneys" that Heaney mentions in his poem in the background, missing from the first version. As mentioned earlier, Paul Durcan has similarly used it in his poem "The Children of Lir - after Hugo Simberg", which also draws on Irish mythology and is set in contemporary Dublin ${ }^{42}$. Unlike Durcan's more personal poem, however, Heaney's "Known World" focuses on the relationship between poetry and the visual arts, and violent conflict and crisis. The poem is set in the Balkans, in the Struga poetry festival in what is now known as the Former Yugoslav Republic of Macedonia. It examines the responses of artists and poets to suffering in a geographical setting of one of the worst nightmares in post-World War II Europe, but also establishes a Finnish context early on as it mentions the contem-

41. Pekka Vähäkangas, "Paikallisuus ja kansallisuus suomalaisessa kuvataiteessa” ("Locality and nationality in Finnish visual arts"), a lecture at the University of Jyväskylä, 1 November 1999, [http://www.finnica.fi/luennot/99syys/ vahakangas.htm], date accessed 14 January 2014.

42. I have previously discussed Heaney's poem in the context of Irish responses to Simberg's painting in "Seamus Heaney, Paul Durcan and Hugo Simberg's Wounded Angel”, see Anne Karhio, "Seamus Heaney, Paul Durcan and Hugo Simberg's 'Wounded Angel'”, Nordic Irish Studies, Vol. 11, n 1, 2012, p. 27-38. 
porary Finnish-Swedish poet Caj Westerberg, "A Finnish Hamlet in black corduroy ${ }^{43}$ ". After introducing its contemporary setting, the poem returns "On the short and sweetening mud-slide of a coffee" to what, one presumes, is the poet's childhood home in Northern Ireland, only to move on to the landscape of Simberg's painting.

In his introduction to an exhibition of works selected by the poet himself from the holdings of the Ulster Museum, Heaney noted how he chose "paintings, photographs and objects that housed some charge of primal energy or embodied some remembered feeling 44 ". That "charge" from a "remembered feeling" aptly describes the numerous poems which focus around his childhood home in Derry, that focus which has energized so much of his work; as Daniel Tobin puts it, "the image of the sacred center stands as a governing trope within [Heaney's] growing body of work ${ }^{45}$ ". In "Known World", too, the passage from Struga to Simberg's landscape needs to pass through the childhood kitchen:

At the still centre of the cardinal points

The flypaper hung from our kitchen ceiling,

Honey-strip and death-trap, a barley sugar twist

Of glut and loathing...

In a nineteen-fifties

Of iron stoves and kin groups still in place,

Congregations blackening the length

And breadth of summer roads ${ }^{46}$.

The childhood home is described in bitter-sweet terms: the "honey-trap" signals delight and death in equal terms. There is no place or time that would retain its innocence, as the poet is questioning the causes and purposes of suffering spatially from the double coordinates between Northern Ireland and the Balkans, and temporally between the 1950s and the 1990s. It is through paintings, however, that the poem can access a geographically nonspecific framework, which is also less conditioned by specific moments in history, and concerned with the universal fragility of the human condition.

The introduction of Simberg's painting is in Heaney's poem preceded by a reference to Breughel's "Fall of Icarus" and Auden's discussion of it in his "Musée des Beaux Arts" (1938): “That old sense of tragedy going on/Uncomprehended,

\footnotetext{
43. Seamus Heaney, Electric Light, London, Faber and Faber, 2001, p. 19.

44. Quoted in Longley, "Poems about Paintings", p. 237.

45. Daniel Tobin, A Passage to the Center: Imagination and the Sacred in the Poetry of Seamus Heaney, Lexington, Kentucky, The University Press of Kentucky, 1998, p. 2.

46. Heaney, Electric Light, p. 20.
} 
at the very edge/of the usual, it never left me once ${ }^{47}$." Auden's poem famously locates hurt and suffering in the margins of a larger landscape canvas: "About suffering they were never wrong,/The Old Masters: how well they understood/Its human position; how it takes place/While someone else is eating or opening a window or just/walking dully along ${ }^{48}$." But the two paintings that the poem refers to differ drastically in their positioning of tragedy. If Breughel's depiction of the misfortune of the falling Icarus takes place in the periphery of vision, in a corner where one merely sees "white legs disappearing into the green", Simberg's landscape is merely a desolate backdrop for the characters at the centre of the image, and invites the viewer to fill it with familiar markers. For Hartnett's haunted Sibelius, music offers an access to the nonverbal realm where art can help address, if not quite obliterate, cultural divides demarcated by language. In Heaney's reading of Simberg, however, the painting can help address hurts which may have been caused by such divides, but are in the end too deep or complex for words. Heaney refers to "The Wounded Angel" as "Hygo [sic] Simberg's allegory of Finland", though the allegory is one that purposely steers clear of any national(ist) contextualisation. Heaney's poem describes the painting as

The one where the wounded angel's being carried

By two farm youngsters across an open field:

Marshland, estuary light, a farther shore

With factory chimneys. Is it the socialist thirties

Or the shale and slag and the sloblands of great hurt?

A first communion angel with big white wings,

White bandage round her brow, white flowers in hand,

Holds herself in place on a makeshift stretcher

Between manchild number one in round soft hat

And manchild number two in a bumfreezer

And what could be his father's Wellingtons.

Allegory, I say, but who's to know

How to read sorrow rightly, or at all ${ }^{49}$ ?

Heaney is unsure whether to read the painting through a historical and social or a personal lens, as a depiction of "the socialist thirties" or "the sloblands of great hurt". He then proceeds to a lengthy description of the painting and its characters, and answers his own question with another: "Allegory, I say, but who's to know/How to read sorrow rightly, or at all?" The sorrow and pain which in "The

47. Ibid., p. 21.

48. W. H. Auden, Collected Shorter Poems, 1930-1944, London, Faber and Faber, 1950, p. 19.

49. Heaney, Electric Light, p. 21. 
Wounded Angel" are decontextualized and embedded in an undefined landscape can, the poet contends, be only interpreted in the form of a question.

In "Sibelius in Silence" music is evoked as a landscape of its own, and painting here serves a similar purpose: the non-referential (or at least the referent is an emotion rather than any specific moment or place outside the painting) topography of Simberg does not seek to place its subject-matter into an explanatory context. The language Heaney uses to describe the painting, however, depicts its objects in a way which link it to a place and landscape closer to home: "the first communion angel" and the boy "in his father's wellingtons" fill the barren lakeshore with familiar points of reference, as the poet maps, through the Finnish artist's ambiguous terrain, a "passage to the center" (as Tobin titles his study on Heaney) which so strongly characterizes his work.

For Heaney, the ekphrastic potential of Simberg's painting lies not solely in aesthetic and formal distancing (Longley) or social/historical commentary (Murphy) but somewhere between the two. The positioning of the figures in the landscapes of Breughel and Simberg allows the poet to interrogate the positioning of suffering not only geographically, but also in relation to poetry and artistic practice: the poets gathered in the Struga festival enjoy the privilege of escaping their more domestic crises, which nevertheless haunt Heaney as the memory of his childhood home leads him to consider atrocities which would take place in the 1990s Balkans. The more exalted, or even detached, aspirations of the poetic profession are questioned as the festival delegates finally soar above the troubled landscape in the jets that carry them home: the final line of the poem reads "Nema problema. Ja. All systems go", and the lines are suspended between the placeless comfort of international aviation and the embodiment of hurt in Simberg's landscape of the mind.

Music and painting have thus provided Hartnett and Heaney with frameworks for interrogating questions of personal and cultural crisis and continuity on the one hand, and, on the other, for exploring the limits of poetry as a verbal art. For Tom Paulin, however, the Finnish landscape provides a possibility for questioning the relationship between bourgeois aestheticism and political agency, or "stillness" and "history". Paulin's concern is the art of poetry in particular, specifically the tradition of lyric poetry and its position between societal engagement and more inward-looking aesthetic reflection, or what Elmer Andrews has described as "frozen... unalterable inertness ${ }^{50}$ ". Paulin's "Trotsky in Finland" draws from Leon Trotsky's memoir My Life, and the period that the revolutionary leader spent in

50. Elmer Andrews, “Tom Paulin: Underground Resistance Fighter”, Poetry in Contemporary Irish Literature, Michael Kennelly (ed.), Gerrards Cross, Buckinghamshire, Colin Smythe, 1995, p. 329. 
exile in the central Finnish countryside in 1905 after his wife's arrest in Russia. The poem closely follows the autobiographical text to describe a moment in time characterized, as Shane Murphy puts it, by "art and stasis ${ }^{51}$ ". Paulin accesses the landscape through Trotsky's text, a context which has already politicized it, but pushes the text and its representation of the Finnish scenery further in order to interrogate the political dimensions of poetry specifically. Murphy contends, in his analysis of the use of intertextuality in Paulin's poem, that "the act of appropriation" of Trotsky's text is in itself a political act for Paulin, and "bricolage can be a transformative praxis ${ }^{52}$ ". As opposed to the two previous poems, in which specific works of art, including their representations of landscape, were recontextualized in the lines of Hartnett and Heaney respectively, in "Trotsky in Finland" landscape is already represented verbally in Trotsky's account. As Paulin rewrites Trotsky's memoir in his poem (as Hartnett does with the biography of Sibelius), the Finnish landscape, going through a poetic metamorphosis of estrangement, remains its visual focus.

The name of the pension where Trotsky stayed was "Rauha", the Finnish for peace, and the surrounding terrain tempts the poem's revolutionary third person protagonist with images "recollected in tranquility":

The air is transparent, perfecting the pine trees and lakes.

He finds himself admiring the stillness of a pure landscape. He consumes it.

A bourgeois moment. It might be somewhere Swiss, The wooden cuckoos calling to an uneventful

Absence, their polyglot puns

Melting in Trieste and Zürich ${ }^{53}$.

Through imaginary displacement, Finland becomes, in the mind of the speaker, Switzerland, the quintessential geographical locus for conservative wealth

51. Murphy, p. 196.

52. Ibid., p. 197.

53. Paulin, Strange Museum, p. 29. The passage that Paulin draws on in Trotsky's memoir goes as follows: The environment in which I lived in Finland, with its hills, pine-trees and lakes, its transparent autumn air, and its peace, was scarcely a reminder of a permanent revolution. At the end of September I moved still farther into the Finnish interior and took up my quarters in the woods on the shore of a lake, in an isolated pension, Rauha. This name in Finnish means "peace". The huge pension was almost empty in the autumn. A Swedish writer was staying there during these last days with an English actress, and they left without paying their bill. The proprietor rushed after them to Helsingfors. His wife was very ill; they could only keep her heart beating by means of champagne. I never saw her. She died while the proprietor was still away. Her body was in a room above me. The head waiter went to Helsingfors to look for her husband. There was only a young boy left for service. A heavy snow fell. The pine-trees were wrapped in a white shroud. The pension was like death. See Leon Trotsky, My Life, [http://www.marxists.org/archive/trotsky/1930/mylife/ch13.htm], date accessed 29 June 2013, n. pag. 
and scenic beauty - the comparison strikes one as oddly, perhaps purposely inaccurate, as southern and central Finland would completely lack the dramatic contours of Swiss mountains. The Finnish landscape is thus doubly displaced in the poem; not only does it implicitly comment on the poetry-politics dialectic in Paulin's native Northern Ireland ${ }^{54}$, but again within the narrative of the poem the scenery reminds the speaker of a landscape more appropriate to that dialectic, as the Swiss setting can be seen as the complete symbolic opposite to the desired outcome of revolutionary Russia. The bourgeois decadence may extend to poetic craft, the speaker implies, and rest on a false ideology of meaningless aesthetic practice that the Finnish pine woods inspire: "The Swedish writer/Adds another sonnet to his cycle ${ }^{55}$." The poet's mistress, too, is caught in the perfection of her own face "bloomed in the smooth lake", and "At night her giggles and frills dismay/The strictness of minor art ${ }^{56 "}$; she is vain and self-absorbed, as is the sonnet-writer's "minor art" (the rather overstated assonance or "bloom"-"smooth" and "night"-"giggles"- "frill" further underlines the idea of a rather purposeless aesthetic). The sonnet here seems to stand for the ultimate expression of a firstperson bourgeois and romantic lyric: in the traditional writer/speaker of a sonnet, as Marjorie Perloff has noted of the continuities between romantic and modernist lyric, "the isolated speaker [...], located in a specific landscape, meditates or ruminates on some aspect of his or her relationship to the external world, coming finally to some sort of epiphany ${ }^{57 "}$. But for Paulin, "there are no imaginative exits from history ${ }^{58}$ ", no comforting escapism to a transcendent domain. In "Trotsky in Finland", therefore, no epiphany is forthcoming, and the poet and his mistress "leave without paying their bill": do their aesthetic preoccupations result in nothing but financial failure, a failure even to sell their "minor art" within the system of bourgeois market capitalism? The flimsy Englishwoman's futile vanity is paralleled by the pension proprietor's dying wife, who is drinking champagne, of all things, "to keep her heart beating": similarly, however, as with the frivolous

54. See Murphy, p. 195.

55. Paulin, The Strange Museum, p. 29.

56. Ibid., p. 29.

57. See Marjorie Perloff, The Dance of the Intellect: Studies in the Poetry of the Pound Tradition. Northwestern University Press, Evanston, Illinois, 1996, p. 156-157. The tradition of the modernist/romantic lyric has frequently, as Perloff has often stressed, placed a certain emphasis on inward-looking reflection by the poet/speaker, at the cost of opening up to the less individualistic energies of language as a shared medium. It should be noted, however, that despite the "retreat into a mental sanctuary" in the work of many of the best known Romantic poets, the Romantic sonnet, too, emerged in a poetic culture closely linked with the social circumstances of the time. Or as Stuart Curran puts it, "if we robe all Romanticism in the priestly vestments in which Keats imagined himself garbed in one poem, judging the period uniformly as characterized by a profound isolation or interiority, we do so only by blinding ourselves to the social and political manifestations of literature of during the age", "Romantic poetry: why and wherefore?", The Cambridge Companion to British Romanticism, Cambridge University Press, Cambridge, 2010 (1993), p. 211.

58. Tom Paulin, Minotaur, London, Faber and Faber, 1992, 5. 
aesthetics of the Swedish-English couple, the luxuries available to her class fail to offer meaningful solutions for life, and she dies "While her husband screams for money". Wealth and cultural status become, in Paulin's poem, signs of death and decay.

That the pension is "insanely traditional" is not something mentioned in Trotsky's original text. Paulin sets these words immediately after the description of the dead calm of the landscape with falling snow, which draws attention to the "Swiss" (bourgeois capitalist) qualities of the setting. Here, too, the dead calm of the scenery is emphasized in both texts: "A thick snow is falling, the house/ Is a dead monument", drawing from Trotsky's "Her body was in a room above me. The head waiter went to Helsingfors to look for her husband... A heavy snow fell ${ }^{59}$." The loneliness of the pension, the winter woods, and the deceased woman's body upstairs mark a dead calm before a storm, before Trotsky "crosses the frontier and speaks/to a massed force at the institute". Finland is thus here a temporary location between bourgeois west and revolutionary east, almost a nonplace before frontier-crossing, symbolically as well as geographically. It is a place from which Trotsky can "[plunge] from stillness into history ${ }^{60}$ ". The stillness of rural Finland is similarly evoked in "A Partial State", also published in A Strange Museum, where the surrounding landscape is "Intractable and northern" and in which a silence or stagnation of a much brooding kind prevails: "Stillness, without history;/until leviathan spouts,/bursting through manhole covers ${ }^{61}$." Thus, in a (Northern) Irish poem written during the Troubles by perhaps the most openly political of poets, a geopolitical location marked by stagnation and the proximity of border evoke another region altogether ${ }^{62}$. The death-like beauty of its landscape thus becomes, for Paulin, an embodiment of the Irish political stalemate.

But while Paulin's poem can be seen to portray an awareness of romantic lyric transcendence, he sees the landscape as described by Trotsky more in terms of

one of those moments in Tolstoy which come across with an intense freshness. We know that Trotsky read Schopenhauer, and these visionary descriptions of landscape are moments that Schopenhauer calls Vorstel-

59. Trotsky, n.pag.

60. Paulin, Strange Museum, p. 30.

61. Ibid., p. 18.

62. In an interview, Paulin has also acknowledged that there is a certain symbolic significance in the North-South dichotomies in poetry. To John Brown's question on "a chain of associations with the 'hyperborean north' (Finland, Russia, Belfast, Iceland) which starkly contrasts with the ... warmer south”, Paulin lists a number of poets drawing on the north-south division and notes, "It's certainly one of the big themes in many writers' work ... So many have written so seriously on the matter that I'm not sure there is much to add". (John Brown, "An Interview with Tom Paulin", In the Chair: Interviews with Poets from the North of Ireland, Salmon Publishing, Cliffs of Moher, Co. Clare, 2002, p. 158.) 
lung. Now if you're a Marxist you say that the admiration of landscape is a form of bourgeois consumption, but that's rubbish because the way in which Tolstoy conveys landscape goes beyond that. And so, too, with this moment in Trotsky. His description of the guest-house, the writer and his mistress, evokes a kind of Chekovian flimsiness $[\ldots]^{63}$.

Schopenhauer's Vorstellung, the subjectivity-in-object of representation or any element in observed reality, makes the landscape of the poem an intersection of the speaker's contemplation and phenomenal perception. Paulin's Trotsky, the poet suggests, is "self-conscious and ironic" in the re-written passage in his description of "a private moment outside the process of history" ${ }^{64 "}$ an awareness of such ironic distance is, perhaps, also echoed in the use of third person, rather than first, in the poem's narrative.

The poem also interrogates poetry's role as an embodiment of bourgeois aesthetics on the one hand, and, on the other, as a means of revolutionary action through the arts in its evocation of Lord Byron, the romantic poet who here exemplifies hereditary privilege and the revolutionary impulse at the same time, through his background in English nobility and his fight in the Greek War of Independence. Paulin's Trotsky moves between the stillness of the bourgeois setting and the prospect of action as the postman carries newspapers reporting on the spreading strike in St. Petersburg. He contemplates: "If this were a fiction, it would be Byron/Riding out of the Tivoli Gardens, his rank/And name set aside. Forced by more than himself ${ }^{65}$." The poem links the bourgeois contemplation of a landscape with the art of sonnet-writing, drawing on the romantic tradition where the poem seeks to capture the essence of a moment, or "the ideal instant" as Jennifer Ann Wagner notes on Wordsworth's sonnets ${ }^{66}$.

But the opposition in the poem is not a simple contrast between art and politics; as Shane Alcobia-Murphy rightly suggests, Paulin does not aim to create "a strict binary opposition between artistic creation and political action ${ }^{67}$. Instead, the lines examine poetry as suspended between social and political motives (and motifs), and pure aesthetics, imagined outside history. Perhaps the term "outside history" should be understood less as an actual possibility of entirely apolitical verse (as Paul Muldoon notes through the voice of Louis MacNeice in "7, Middagh Street", "the very painting of [an] oyster/is in itself a political gesture", certainly in late twentieth-century Northern Ireland), than as Paulin's desire, as

63. John Haffenden, Viewpoints: Poets in Conversation, London, Faber and Faber, 1981, p. 168.

64. Ibid., p. 169.

65. Paulin, Strange Museum, p. 30.

66. Jennifer Ann Wagner, A Moment's Monument: Revisionary Poetics and the Nineteenth-Century English Sonnet, London, Associated University Presses, 1996, p. 16.

67. Ibid., p. 197. 
Elmer Andrews has stressed, to challenge the Arnoldian view of poetry's "capacity for neutrality by which 'culture stands apart from a world of passions' and achieves 'an eminence outside history'". For Paulin, this is the flawed premise that poems "exist in a timeless vacuum of a soundproof museum, and that poets are gifted with the ability to hold themselves above history, rather like skylarks or weather satellites ${ }^{68}$.

In their own ways, all of the three poems discussed above address the possibility of finding a position which would subvert the limitations of a single historical or geographical context, something "outside history" in another sense, the shared ground, the familiar in the foreign: Sibelius's desire for the "cold pure water" of music, Heaney's fascination with the non-specificity of Simberg's landscape as a depiction of universal human condition, and Paulin's Finland as a poetic borderland between the Western bourgeois aesthetic and the ideologies of revolutionary Russia. Indeed, the approaches of Hartnett and Heaney might be seen to offer an alternative to Paulin's dynamics of social engagement versus aesthetic detachment, as they address the possibility of perspectives beyond the immediate demands of their historical situations in music and painting respectively. Rather than bourgeois detachment, this underlines art and poetry's potential to question the boundaries of any specific personal, political, cultural, linguistic and historical context.

As Longley points out in her essay, "mobility [is] now routine" in the lives of Irish poets in a way which makes it easy to find poems drawing on poets' experiences in the European continent, America or Japan ${ }^{69}$. But while a certain amount of "routine mobility" may be behind the engagement of poets with Finland (Heaney, for example, encountered Simberg's painting during a poetry reading visit to Finland and his visit to the Tampere Cathedral ${ }^{70}$, the encounters behind the poems discussed above are situated in the "complex mesh of internal and external, physical and intellectual contexts" that doesn't constitute an orderly or coherent critical narrative ${ }^{71}$. The poems and their Finnish contexts do not exactly result from a need of addressing personal experiences of travel in lyric poetry, but rather from poets finding shared preoccupations in works from another historical era and geographical setting. Perhaps it might be less accurate to speak of "texts circulat[ing] without contexts", than of contexts being too easily imagined solely within the framework of national-geographical boundaries. Instead, the particular circumstances of writers and artists in themselves constitute contexts which draw on experiences shared regardless of one's place or time

68. Quoted in Andrews, p. 329-330.

69. Longley, "Internationalism”, p. 49.

70. Personal conversation with the poet in Vienna, 1 September 2008.

71. Ibid. 
of origin. Hartnett, after all, had, as Paul Durcan notes, "a lifelong preoccupation with the music and person of the Finnish composer ${ }^{72 "}$, one which included the Irish poet seeing a kindred spirit in an artist haunted by alcoholism. Durcan himself ended up listening to Sibelius due to his admiration of Hartnett ${ }^{73}$, and has also, like Heaney, engaged with Simberg's painting by choosing it as the cover illustration of his collection Daddy, Daddy (1990), and as the framework for "The Children of Lir - After Hugo Simberg". The location of Tom Paulin's poem draws on his interest in Russia and its revolution, and the points of comparison with his own revolutionary impulses as a poet from the North of Ireland, perhaps more so than on any particular fascination with Russia's small Northwestern neighbour. In as much as "any poet seizes on the familiar in the foreign", for Hartnett, Heaney and Paulin, the engagement with Finnish artists and landscapes has less to do with Finnish-Irish relations or "internationalism" than with elements encountered in particular artworks or texts, appropriate to their concerns and preoccupations. Hartnett's Sibelius inhabits a landscape populated, colonized and reclaimed, which yields to an interrogation of artistic responsibility to a similar process undergone by the territory of Ireland; the barren landscape of Simberg's painting yields to Heaney's exploration of shared experiences of hurt in late $20^{\text {th }}$ century Balkans and Ireland; Paulin's Trotsky retreats to rural Finnish landscape which becomes an allegory for concerns of a similar retreat to aesthetic isolation in Irish literature and the arts during the Troubles. The works encountered in the poetic texts discussed in this essay thus provide the three poets with symbolic landscapes through which to familiarize the strange, make strange the familiar, and to recontextualize personal and historical moments of crisis.

72. Durcan, "Hartnett's Farewell”, p. 198.

73. Ibid., p. 199. 